\title{
MODEL PEMBELAJARAN PROJECT BASED LEARNING (PBL) DALAM MENINGKATKAN KETERAMPILAN MENULIS TEKS DRAMA PADA SISWA MTS AL QOMARIYAH GARUT
}

\author{
Deni Hadiansah \\ Fakultas Ekonomi, Universitas Insan Cendekia Mandiri, Kota Bandung \\ denihadiansah@gmail.com \\ Desty Rara Pringgandinie \\ Fakultas Keguruan dan Ilmu Pendidikan, Universitas Insan Cendekia Mandiri, Kota Bandung \\ destyrara@gmail.com \\ Rani Rabiussani \\ SMK Negeri 13 Bandung, Kota Bandung \\ denihadiansah@gmail.com \\ Yun Yun Qurota Ayunin \\ MTs Al Qomariyah, Kabupaten Garut \\ yunyunqurotaayun76@gmail.com
}

\begin{abstract}
Abstrak
Penelitian ini bertujuan mendeskripsikan penerapan model pembelajaran Project Based Learning (PBL) dalam meningkatkan keterampilan menulis teks drama pada siswa MTs Al Qomariyah Garut. Penelitian ini menggunakan pendekatan kuantitatif dengan desain quasi eksperimen nonequivalent control group design. Dari populasi siswa sejumlah 252 orang, diambil sampel 60 siswa terdiri dari Kelas VIII A-1 (Eksperimen) 30 siswa dan Kelas VIII B-1 (Kontrol) 30 siswa. Hasil penelitian menunjukkan bahwa kemampuan siswa dalam meneulis teks drama dengan model PBL rerata nilai pretes 67,66 dan rerata nilai postes 87.50. Adapun kemampuan siswa yang menggunakan model Direct Instruction (DI) rerata nilai pretes 60.00 dan rerata nilai postes 79.50. Artinya hipotesis diterima, kemampuan siswa dalam menulis teks drama melalui pembelajaran model PBL lebih baik daripada pembelajaran menggunakan model DI. Adapun gambaran kemampuan keterampilan berbahasa yang lain pada siswa MTs Al Qomariyah Garut, tentu saja perlu dilaksanakan penelitian lanjutan.
\end{abstract}

Kata Kunci: menulis, project based learning, teks drama

\begin{abstract}
This study aims describe the application of the Project Based Learning (PBL) learning model in improving the writing skills of drama text in MTs Al Qomariyah Garut students. This study used a quantitative approach with a quasi-experimental design nonequivalent control group design. From a student population of 252 people, a sample of 60 students was taken consisting of Class VIII A-1 (Experiment) 30 students and Class VIII B-1 (Control) 30 students. The results showed that the students' ability to write drama texts with the PBL model had the mean pretest score of 67.66 and the average post-test score of 87.50. As for the ability of students who use the Direct Instruction (DI) model the mean pretest score is 60.00 and the average posttest score is 79.50. This means that the hypothesis is accepted, the students' ability in writing drama texts through PBL model learning is better than learning using the DI model. As for the description of other language skills skills in MTs Al Qomariyah Garut students, of course, further research needs to be carried out.
\end{abstract}

Keywords: writing, project based learning, drama text

\section{PENDAHULUAN}

Dalam Kurikulum 2013 mata pelajaran bahasa Indonesia di SMP/MTs., terdapat empat keterampilan berbahasa yang harus dikuasai siswa, meliputi: menulis (writing), menyimak (listening), berbicara (speaking), dan membaca (reading). Pada konteks pembelajaran di dalam kelas, istilah 
menulis sering disamakan dengan kegiatan mengarang siswa. Menurut Wulandari (2020:303) menulis adalah kegiatan seseorang untuk memproduksi tulisan. Dengan menulis seseorang dapat menyampaikan ide, pesan, dan idenya kepada orang lain. Oleh karena itu, dalam konteks pembelejaran bahasa, menulis termasuk ke dalam keterampilan produktif. Melalui tulisan, pada dasarnya siswa dapat berimajinasi, mengekspresikan, dan mengkomunikasikan perasaan, gagasan, dan pikirannya.

Demi menyusun tulisan yang baik, beberapa pakar mengajukan langkahlangkah, meliputi: prewriting, writing, dan rewriting (McCrimmon, 1972: 3; Mccuen Metherell \& Wincler, 2009: 1-4). Adapun Grenville (2001:190) membagi tahapan langkah menulis menjadi enam langkah, yaitu: (a) menentukan gagasan; (b) memilah dan memilih gagasan; (c) menyusun garis besar; (d) menyusun kerangka tulisan; (e) melakukan pemeriksaan; dan (f) memperbaiki tulisan.

Kaitannya dengan pembelajaran bahasa, keterampilan menulis dianggap paling sulit dibandingkan dengan tiga keterampilan berbahasa lainnya. Menulis adalah keterampilan yang rumit dan kompleks (Mastan \& Maarof, 2014: 2361). Menurut Graves (1978:14) seseorang tidak terampil menulis karena tidak tahu tujuan, merasa tidak berbakat dan tidak memamhami teknis menulis. Anggapan sulitnya keterampilan menulis oleh siswa di sekolah, menurut Smith (1981:28) terpengaruh kondisi guru yang tidak mampu menulis dan pandai mengajarkannya. Adapun secara umum, menurut Darmadi (1996:11) permasalahan yang dihadapi penulis berkaitan dengan kondisi perasaan takut memulai, tidak tahu kapan waktunya harus memulai, kesulitan mengorganisasikan gagasan, dan penguasaan bahasa sasaran.

Salah satu keterampilan menulis yang harus dikuasai oleh siswa SMP/MTs adalah genre karya sastra drama atau teks drama. Pada Kurikulum 2013 Bahasa Indonesia SMP/MTs, menulis teks drama adalah Kompetensi Dasar (KD) 4.16 yaitu "Menyajikan drama ke dalam bentuk pentas atau naskah". Tujuan akhir pembelajarannya, siswa mampu menyajikan drama baik dalam bentuk pergelaran (pentas) maupun dalam bentuk teks drama (naskah).

Keterampilan menulis teks drama pada dasarnya adalah kreativitas mengorganisasikan gagasan secara imajinatif dan teknis untuk menghasilna sebuah naskah drama. Penulis perlu kemampuan dalam mengorganisasikan penokohan, pengaluran, dialog, monolog, dan unsur-unsur karya sastra drama lainnya. Pada akhirnya naskah hasil karyanya dapat dipergelarkan atau dipentaskan. Maka muncul istilah naskah drama dan pentas drama. Menurut Waluyo (2001:2) keduanya akibat persinggungan teks drama (Waluyo, 2001:2). Adapun menurut Putra (2012: 25) keberadaaan naskah drama sangat menunjang dalam pementasan drama. Para pemain drama akan merujuk alur penceritaan, penokohan, pelataran, dan ragam ekspresi pentas berdasarkan dari naskah yang dibacanya.

Berdasarkan hasil wawancara pendahuluan pada MTs Al Qomariyah Garut, ditemukan beberapa keluhan siswa dan guru mata pelajaran bahasa Indonesia. Siswa mengeluh karena dalam pembelajaran menulis teks drama, guru banyak menggunakan metode konvensional ceramah. Selain itu, waktu belajar terasa kurang mengingat pembelajaran menulis teks drama sulit. Adapun dari pihak guru, sekolah masih kekurangan fasilitas multimedia dalam pembelajaran drama. Selain itu, guru masih ragu-ragu untuk mencoba model pembelajaran baru selain ceramah. Hal ini sejalan dengan fakta umum yang terjadi bahwa menulis karya sastra salah satunya drama, seseorang mengalami kesulitan untuk mengekspersikan gagasan yang akan dituliskannya (Achmad, 2016:9).

Berdasarkan problematika di atas, maka peneliti mencoba menawarkan solusi kepada guru mata pelajaran bahasa Indonesia untuk melihat penerapan model aktual dalam pembelajaran menulis teks drama, yaitu model pembelajaran Problem Based Learning (PBL). Menurut Somodana, Sutresna, dan Indriani (2015:2) 
bahwa PBL sebuah model yang memerlukan keterlibatan siswa dalam kegiatan pembelajarannya atau berpusat pada siswa. Akcay et al. (2009) menyatakan melalui PBL siswa akan termotivasi untuk berkolaborasi memecahkan masalah yang dihadapinya. Adapun menurut Bound dan Falleti (dalam Demitra, 2003) menyatakan bahwa PBL berbasis pendekatan konstruktivistik dengan karakteristik kontekstual, kolaboratif, metakognitif, dan memecahkan masalah. Oleh karena itu, pembelajaran akan lebih bermakna dan mendorong siswa dalam berpikir tingkat tinggi. PBL dapat membelajarkan siswa dalam memahami masalah yang dihadapinya dengan prinsip ill-structured atau open ended melalui pemberian stimulus dalam kegiatan pembelajarannya. Pada model pembelajaran ini, artinya siswa didorong untuk bekerja sama dalam kelompok atau komunitas belajar.

Berdasarkan paparan di atas, model PBL menjadi alah satu metode yang selaras dengan tuntutan Kurikulum 2013. Selaras pula dengan konsep belajar konstruktivistik yang berorientasi student centered learning demi mencipta siswa yang kreatif, kolaboratif, berpikir metakognitif, lebih bermakna, dan melatih kemandirian siswa untuk memecahkan masalah yang di hadapinya. Dalam perspektif Yuan (2008) PBL merupakan model pembelajaran dengan prinsip student centre, partisipatif, siswa dalam kelompok kecil untuk memecahkan masalah yang sedang dihadapinya dalam kegiatan belajar. Selanjutnya Arends (2009) mengemukakan sintaks PBL terdiri dari: (a) orientasi masalah siswa; (b) mengorganisasikan siswa; (c) membimbing kelompok investigasi; (b) menyajikan hasil karya; dan (e) mengevaluasi proses pemecahan masalah.

Kaitannya dengan pembelajaran pembelajaran bahasa Indonesia, model PBL ini dianggap cocok dalam mendorong keterampilan menulis siswa. Menurut penelitian Kurnia (2015) model PBL dapat meningkatkan keterampilan siswa SMA dalam menulis teks eksposisi. Kajian lain yang dilakukan oleh Kristyanawati,
Suwandi, dan Rohmadi (2019) menyatakan bahwa model PBL terbukti dapat meningkatkan keterampilan menulis teks despkripsi siswa SMA.

Kemudian berkaitan dengan pembelajaran menulis pada MTs, telah banyak dilakukan oleh beberapa peneliti. Puspitasari dan Bakti (2014) melakukan penelitian terhadap keterampilan menulis dongeng pada siswa MTs Mu'allimin Malebo. Hasilnya menunjukkan bahwa media film dapat dijadikan alternatif oleh guru dalam strategi meningkatkan keterampilan menulis siswa. Adapun khusus penelitian yang berkaitan dengan dengan keterampilan menulis teks drama pada siswa MTs, telah dilakukan oleh Novitasari, Sutrimah, dan Hasanudin (2020). Hasil penelitian menujukkan bahwa pembelajaran quantum sangat cocok untuk mendorong kemampuan siswa kelas VIII MTs. Darussalam Deru Bojonegoro dalam menulis teks drama. Selanjutnya, kajian Sari dan Lubis (2017) mengungkap dengan pembelajaran aktif, kemampuan menulis naskah drama siswa kelas VIII MTs Nurul Khairiyah dapat meningkat.

Berdasarkan paparan di atas, jelas bahwa PBL termasuk salah satu model pembelajaran yang selaras dengan pelaksanaan Kurikulum 2013 Mata Pelajaran Bahasa Indonesia di MTs. Selain itu, menurut beberapa hasil kajian model PBL pun dapat meningkatkan keterampilan menulis siswa MTs. Hanya saja, fakta di lapangan menunjukkan bahwa siswa MTs Al Qomariyah Garut masih mengalami kesulitan dalam pembelajaran menulis teks drama. Oleh karena itu, penelitian ini akan mengkaji tentang implementasi model pembelajaran PBL dalam meningkatkan keterampilan menulis teks drama pada siswa MTs Al Qomariyah Garut.

\section{METODE}

Pendekatan yang digunakan dalam penelitian ini adalah kuantitatif (Quantitatif Aproach). Desain penelitiannya adalah desain quasi eksperimen melalui nonequivalent control group design. Menurut Sugiyono (2017) desain ini memiliki kesamapaan dengan desain pretest-postest control group design, tetapi 
pemilihan kelompok kontrol tidak dipilih random. Pada penelitian ini akan digunakan dua kelas sebagai kelas ekeperimen yang diberi perlakuan dengan penggunaan model PBL dan kelas kontrol yang menggunakan metode DI. Pada akhir penelitian, rerata nilai postes kedua kelas tersebut akan dilihat perbedaannya untuk menetukan adanya peningkatan hasil belajar yang siginifikan pada kemampuan menulis teks drama siswa.

Populasi penelitian ini adalah siswa pada MTs Al Qomariyah yang berjumlah sebanyak 252 orang, terdiri dari 9 rombongan belajar yang terbagi ke dalam Kelas VII, VIII, dan IX. Adapun yang dijadikan sampel adalah Kelas VIII A-1 sebanyak 30 siswa dan Kelas VIII B-1 sebanyak 30 siswa. Kelas A-1 dijadikan kelas eksperimen dan diberi kode A-1 (Eksperimen), sedangkan kelas B-1 dijadikan kelas control dan diberi kode B-1 (Kontrol).

Penelitian dilaksanakan pada bulan September - November 2019, sebelum adanya pandemi Covid-19 dan kegiatan pembelajaran masih tatap muka.

\section{HASIL DAN PEMBAHASAN}

Penelitian dilaksanakan pada MTs Al Qomariyah pada masa sebelum pandemi Covid-19 dan kegiatan pembelajaran masih berlangsung tatap muka, yaitu pada tanggal 4-5 November 2019. Adapun tujuan penelitian ini untuk mengetahui peningkatan kemampuan siswa pada materi menulis teks drama dengan menggunakan model PBL.

Penelitian dimulai dengan penyusunan instrumen dan Rencana Pelaksanaan Pembelajaraan (RPP) dengan dua desain. Desain pertama RPP yang kegiatan pembelajarannya menggunakan model PBL untuk diimplementasikan pada kelas A-1 (Eksperimen), sedangkan desain kedua RPP yang kegiatan pembelajarannya menggunakan model DI untuk diimplementasikan pada kelas B-1 (Kontrol). Tahap selanjutnya adalah proses pembelajaraan dengan menggunakan dua desain RPP tersebut.

Sebelum dilaksanakan proses pembelajaran, dilaksanakan uji validitas atau kesahihan instrumen. Secara teknis, pengujian validitas soal tes yaitu dengan cara skor yang diperoleh per soal dikorelasikan dengan total skor. Berikut ini disajikan hasil uji validitas terhadap instrumen dalam penelitian.

Tabel 1. Hasil Uji Validitas Instrumen

\begin{tabular}{|c|c|c|c|}
\hline No & $\begin{array}{c}\text { Nilai Koefisien } \\
\text { Validitas }\end{array}$ & Kriteria & Kategori \\
\hline 1 & 0,435 & Valid & Sedang \\
\hline 2 & 0,446 & Valid & Sedang \\
\hline 3 & 0,683 & Valid & Tinggi \\
\hline 4 & 0,520 & Valid & Sedang \\
\hline 5 & 0,702 & Valid & Tinggi \\
\hline
\end{tabular}

Berdasarkan Tabel 1., dinyatakan bahwa soal yang digunakan untuk penelitian masuk ke dalam kriteria valid dengan kategori sedang dan tinggi. Simpulan pernyataan kriteria di atas, merujuk pada perolehan nilai korelasi antara skor per soal dengan skor total ( $\left.\mathrm{r}_{\text {hitung }}\right)$ kemampuan menulis teks (drama) yang telah diperoleh. Hasil tersebut, kemudian disandingkan sekaligus dibandingkan dengan nilai $r_{\text {tabel }}$ berada pada signifikasi 0,05 dan jumlah data (n) $=30$. Prinsip kriterianya, apabila $r_{\text {hitung }} \geq r_{\text {tabel }}$ skor per soal dinyatakan valid. Sebaliknya, apabila $\mathrm{r}_{\text {hitung }}<\mathrm{r}_{\text {tabel, }}$ maka skor per soal dinyatakan non-valid atau tidak valid. Pada hitungan lain, diperoleh nilai $\mathrm{r}_{\text {tabel }}$ pada $\alpha=$ $0,05 \mathrm{dan} \mathrm{dk}=30$ yaitu 0,361 . Oleh karena itu, berdasarkan hasil uji validitas maka butir-butir soal untuk tes kemampuan siswa dalam menulis teks drama termasuk ke dalam kategori atau kriteria valid. Hal tersebut berdasarkan perolehan nilai $\mathrm{r}_{\text {hitung }} \geq$ $\mathrm{r}_{\text {tabel, }}$ maka termasuk kriteria valid.

Selain uji validitas, selanjutnya dilakukan oge uji realibilitas untuk menguji akurasi dan konsistensi instrumen tes yang digunakan dalam penelitian. Pelaksanaan pengukurannya dilakukan dalam rentang waktu yang berbeda. Uji realibilitas menggunakan aplikasi SPSS versi 21 melalui uji statistik Cronbach Alpha. Hasilnya menunjukkan bahwa nilai Alpha yang diperoleh adalah 0,660 , adapun nilai $\mathrm{r}_{\text {tabel }}$ (uji dua pihak) dengan perolehan signifikasi 0,05 pada jumlah $(n)=30$ dengan perolehan sebesar 0,361 . Sesuai 
hasil hitung, perolehan nilai Alpha >0,361, maka butir-butir instrumen untuk menguji kemampuan siswa dalam menulis teks drama dikatakan reliabel.

Setelah uji instrumen, selanjutnya dilaksanakan proses pembelajaran pada Kelas A-1 (Eksperimen) menggunakan model PBL dan pada kelas B-1 (Kontrol) menggunakan model DI. Pada kegiatan ini, tentu saja dilaksanakan prestes dan postes baik pada Kelas A-1 (Eksperimen) maupun pada Kelas B-1 (Kontrol). Secara prosedural, kegiatan diawali dengan pretes untuk mengetahui kemampuan awal siswa sebelum diberikan perlakuan (treatment). Siswa diberikan penugasan untuk menulis teks drama pendek. Berdasarkan perhitungan dan perolahan pada nilai pretes, maka kemampuan teks drama siswa Kelas VIII A-1 (Eksperimen) sebelum menggunakan model PBL memeroleh rerata nilai 67,66 . Nilai terendah berada pada 45 , sedangkan nilai tertinggi berada pada 75. Data tersebut menunjukkan bahwa kemampuan siswa masih rendah dalam menulis teks drama sesuai indikator yang dikembangkan dalam rencana pembelajaran.

Berdasarkan kondisi tersebut, kemudian peneliti melakukan perlakuan pada kelas tersebut dengan mengimplementasikan model PBL dalam pembelajaran menulis teks drama. Berdasarkan hasil pengolahan terhadap hasil karya siswa, ternyata hasil postes menunjukkan nilai siswa meningkat dengan perolehan rerat nilai 87.50. Nilai terendah berada pada 80 , sedangkan nilai tertinggi berada pada 100. Dengan demikian, artinya terdapat peningkatan hasil belajar pada kelompok siswa dalam menulis teks drama setelah diberikan model PBL.

Adapun pada Kelas VIII B-1 (Kontrol) hasil pretes siswa rerata perolehan nilainya 60.00. Nilai terendah pada angka 40, adapun nilai tertinggi yang diperoleh pada angka 70. Data tersebut menunjukkan bahwa pada kelas kontrol, kemampuan siswa dalam menulis teks drama masih rendah, Setelah itu, kemudian pada Kelas Kontrol tersebut diberikan perlakukan dengan mengimplementasikan model Direct Instruction (DI). Hasil postes menunjukkkan rerata nilai siswa 79.50. Nilai terendah pada angka 75 dan tertinggi pada angka 90. Data tersebut menunjukkan adanya peningkatan kemampuan siswa menulis teks drama antara sebelum dan sesudah diimplementasikan model DI.

Berdasarkan data pada Kelas A-1 (Eskperimen) dan Kelas B-1 (Kontrol), kemudian hasilnya dibandingkan untuk memeroleh gambaran keberhasilan antara pembelajaran menggunakan model PBL dengan model DI dalam meningkatkan kemampuan menulis teks drama siswa. Hal ini dapat terlihat pada rerata nilai pretes, nilai postes, dan indeks gain yang diperoleh baik pada kelas Kelas A-1 (Eskperimen) dan Kelas B-1 (Kontrol) sebagaimana dapat dilihat pada tabel beirkut ini.

Tabel 2. Rerata Nilai Pretes, Nilai Postes, dan Indeks Gain

\begin{tabular}{|c|c|c|c|c|}
\hline \multirow[t]{2}{*}{ Kelas } & \multicolumn{3}{|c|}{ Rerata } & \multirow{2}{*}{$\begin{array}{c}\text { Kategori Indeks } \\
\text { Gain }\end{array}$} \\
\hline & Pretes & Postes & Indeks Gain & \\
\hline Eksperimen & 67.66 & 87.50 & 0.74 & Tinggi \\
\hline Kontrol & 61.00 & 79.50 & 0,51 & Sedang \\
\hline
\end{tabular}

Berdasarkan Tabel 2., dapat dicermati hasil hitungan secara statistik bahwa perolehan rerata nilai pretes kelas A-1 (Eksperimen) yaitu 67.66, adapun nilai rerata untuk pretes kelas B-1 (Kontrol) perolehannya yaitu 61.00. Data tersebut memperlihatkan bahwa perolehan nilai pretes Kelas A-1 (Eksperimen) lebih tinggi dari pada perolehan nilai pada kelas B-1 (Kontrol), meskipun keduanya termasuk pada kategori kurang atau rendah. Oleh karena itu, kemudian dilakukan perlakuan dengan menggunakan model PBL pada Kelas A-1 (Eksperimen) dan model DI pada Kelas B-1 (Kontrol). Berdasarkan hasil postes, diperoleh rerat nilai pada kelas A-1 (Eksperimen) sebesar 87.50, artinya bahwa masuk ke dalam kategori dengan tingkat pemahaman yang baik. Adapun rerata nilai postes pada Kelas B-1 (Kontrol) yang 
diberi perlakukan model DI, perolehan rerata nilanya 79.50 , artinya masuk ke dalam kategori pemahaman cukup. Data ini pun menunjukkan bahwa rerata nilai pada kelas A-1 (Eksperimen) lebih tinggi atau lebih baik daripada rerata nilai pada kelas B-1 (Kontrol). Dengan demikian dapat dinyatakan bahwa model PBL lebih baik daripada model DI.
Pernyataan di atas, diperkuat dengan hasil uji hipotesis. Adapun pengujian atau perhitungannya memakai uji wilcoxon signed rank test pada aplikasi SPSS versi 21, baik pada kelas A-1 (Eksperimen) maupun pada kelas B-1 (Kontrol). Adapun hasil perhitungannya dapat dilihat pada Tabel 3. dan Tabel 4. berikut ini.

Tabel 3. Hasil Uji Hipotesis Kelas A-1 (Eksperimen)

\begin{tabular}{|l|l|r|r|r|}
\hline \multicolumn{5}{|c|}{ Rank } \\
\hline \multicolumn{2}{|c|}{} & \multicolumn{1}{|c|}{$\mathrm{N}$} & Mean Rank & \multicolumn{1}{c|}{ Sum of Ranks } \\
\hline EksPostTest - \\
EksPreTest & Negative Ranks & $0^{\mathrm{a}}$ & .00 & .00 \\
\cline { 2 - 6 } & positive ranks & $30^{\mathrm{b}}$ & 15.50 & 465.00 \\
\cline { 2 - 6 } & ties & $0^{\mathrm{c}}$ & & \\
\cline { 2 - 5 } & total & 30 & & \\
\hline
\end{tabular}

- Eksperimen PostTest < Eksperimen PreTest

- Eksperimen PostTest $>$ Eksperimen PreTest

- Eksperien PostTest $=$ Eksperimen PreTest

\begin{tabular}{cr}
\hline \multicolumn{2}{c}{ Test Statistics $^{\mathrm{a}}$} \\
\multicolumn{2}{c}{ EksperimenPostTest-EksperimenPreTest } \\
\hline $\mathrm{Z}$ & $-4.891^{\mathrm{b}}$ \\
\hline Asymp. Sig. (2-tailed) & .000 \\
\hline
\end{tabular}

- Wilcoxon Signed Ranks Test

- Based on negative ranks

Tabel 4. Hasil Uji Hipotesis Kelas A-1 (Eksperimen)

\begin{tabular}{|l|l|r|r|r|}
\hline \multicolumn{5}{|c|}{ Rank } \\
\hline \multirow{2}{*}{$\begin{array}{l}\text { EksPostTest }- \\
\text { EksPreTest }\end{array}$} & Negative Ranks & $0^{\mathrm{a}}$ & Mean Rank & \multicolumn{1}{c|}{ Sum of Ranks } \\
\cline { 2 - 5 } & Positive Ranks & $30^{\mathrm{b}}$ & .00 & .00 \\
\cline { 2 - 6 } & Ties & $0^{\mathrm{c}}$ & & 45.50 \\
\cline { 2 - 6 } & Total & 30 & & \\
\hline
\end{tabular}

- Kontrol PostTest < Kontrol PreTest

- Kontrol PostTest > Kontrol PreTest

- Kontrol PostTest $=$ Kontrol PreTest

\begin{tabular}{cc}
\hline \multicolumn{2}{c}{ Test Statistics $^{\mathrm{a}}$} \\
EksPostTest - EksPreTest \\
\hline $\mathrm{Z}$ & $-4.816^{\mathrm{b}}$
\end{tabular}

\begin{tabular}{l}
\hline Asymp. Sig. (2-tailed) \\
- Wilcoxon Signed Ranks Test \\
- Based on negative ranks
\end{tabular}

Berdasarkan Tabel 3. dan Tabel 4., pengujian dilakukan dengan uji wilcoxon signed rank test. Uji wilcoxson menggunakan skala nominal dan skala nilai ordinal, sehingga termasuk uji statistik nonparametrik. Berdasarkan hasil di atas, perolehan nilai Ties-nya yaitu ' 0 ', hal tersebut berarti bahwa tidak terdapat nilai yang sama antara nilai pretes dengan nilai postes.

Dengan demikian, berdasarkan output test Statistics dapat terlihat juga perolehan 
nilai Asymp, yang perolehan Sig (2-tailed) yaitu 0,000 atau $>0,05$. Adapun perolehan nilai probabilitasnya, yaitu sig (2 tailed) $<0,05$.

Berdasarkan paparan di atas, maka dapat dinyatakan bahwa terdapat perbedaan hasil kemampuan siswa pada materi menulis teks drama, antara pembelajaran dengan menngunakan model PBL dengan pembelajaran yang menggunakan model DI. Selain itu, dapat juga dinyatakan bahwa kemampuan siswa pada materi pembelajaran menulis teks drama menggunakan model PBL hasilnya lebih baik dari pada pembelajaran menggunakan model DI. Dengan demikian, hipotesis pada penelitian ini dapat diterima.

\section{SIMPULAN}

Berdasarkan hasil pretes pada Kelas VIII A-1 (Eksperimen), kemampuan teks drama siswa memeroleh rerata nilai 67,66. Nilai terendah berada pada 45 , sedangkan nilai tertinggi berada pada 75 . Setelah dilakukan perlakuan dengan model PBL,

\section{DAFTAR PUSTAKA}

Achmad, Sri Wintala. 2016. Menulis Kreatif Itu Gampang. Yogyakarta: Araska.

Akcay, B. 2009. Problem-Based Learning in Science Education. Journal of Turkish Science Education. Vol. 6, No. 1.

Arends, R.I. 2009. Learning to Teach. Boston: McGraw-Hill International Ed.

Darmadi, Kaswan. 1996. Meningkatkan Kemampuan Menulis. Yogyakarta: Penerbit Andi.

Demitra. 2003. Pembelajaran Pemecahan Masalah Matematika Sekolah Dasar dengan Pendekatan Problem Based Learning. Makalah. Disampaikan dalam Seminar Nasional Teknologi Pembelajaran di Hotel Inna Garuda Tanggal 22 - 23 Agustus 2003.

Graves, D.H. 1978. Balance the Basi : Let Them Write. New York: Ford Foundation. kemudian diadakan postes dan hasilnya rerata nilai 87.50. Nilai terendah berada pada 80 , sedangkan nilai tertinggi berada pada 100. Dengan demikian, terlihat adanya peningkatan hasil belajar siswa dalam menulis teks drama setelah diberikan model PBL. Adapun pada Kelas VIII B-1 (Kontrol) hasil pretes siswa rerata perolehan nilainya 60.00 . Nilai terendah pada angka 40, sedangkan nilai tertinggi pada angkata 70 . Setelah dilakukan perlakuan menggunakan model DI rerata nilai siswa menjadi 79.50 . Nilai terendah pada angka 75 dan tertinggi pada angka 90 . Akhirnya, dapat disimpulkan bahwa kemampuan siswa pada materi pembelajaran menulis teks drama melalui model PBL lebih baik dari pada pembelajaran menggunakan model DI. Dengan demikian, dapat dinyatakan bahwa hipotesis diterima. Adapun gambaran kemampuan keterampilan berbahasa yang lain pada siswa MTs Al Qomariyah Garut, tentu saja perlu dilaksanakan penelitian lanjutan.

Grenville, K. 2001. Writing from Start to Finish: A Six-Step Guide. Australia: Allen \& Unwin.

Kristyanawati, Martanti Dwi , Sarwiji Suwandi, Muhammad Rohmadi. 2019. Peningkatan Keterampilan Menulis Teks EksposisiMenggunakan Model Problem Based Learning. Scholaria: Jurnal Pendidikan dan Kebudayaan, Vol. 9 No. 2, Mei 2019, 192-202.

Kurnia. 2015. Penerapan Model Problem Based Learninguntuk Meningkatkan Kemampuan Menulis Teks Eksposisi Pada Siswa Kelas X Iis-4 Sma Negeri 8 Makassar. Jurnal Pepatuzdu, Vol. 9, No. 1, Mei, 72-84. https://media.neliti.com/media/publicat ions/283735-penerapan-modelproblem-based-learning-ude4864e5.pdf

Mastan, M. E., \& Maarof, N. 2014. ESL Learners' Self-efficacy Beliefs and Strategy Use in Expository Writing. Procedia -Social and Behavioral Sciences, 116, 2360-2363. 
McCrimmon, J. M. 1972. Writing with a Purpose (Short Edit). United States Of America: Houghton Mifflin.

Mccuen Metherell, J. R., \& Wincler, A. C. 2009. From Idea to Essay: A Rhetoric, Reader, and Handbook. New York: Houghton Mifflin Harcourt Publishing Company.

Novitasari, Heni, Sutrimah Sutrimah, Cahyo Hasanudin. 2020. Analisis Keterampilan Menulis Teks Drama dengan Pembelajaran Quantum. Jurnal AKSARA, Vol. 6 (2), 2020, 179-190. https://ejurnal.pps.ung.ac.id/index.php/ Aksara/article/view/237

Puspitasari, Eka Harum dan Hari Bakti. 201. Peningkatan Keterampilan Menulis Kembali dengan Bahasa Sendiri melalui Media Film Dongeng pada Peserta Didik Kelas VII B MTs Mu'allimin Malebo Temanggung. Jurnal JPBSI Universitas Negeri Semarang, Vol. 3 (1), 2014, 1-11. http://journal.unnes.ac.id/sju/index.php /jpbsi

Putra, Bintang Angkasa. 2012. Drama Teori dan Pementasan. Yogyakarta: PT Citra Aji Parama.Waluyo, Herman J. 2002. Drama: Teori dan Pengajarannya. Yogyakarta:
Sari, Rizky F., and Fitriani Lubis. Kemampuan Menulis Naskah Drama Siswa Kelas VIII MTs Nurul Khairiyah Sei Tuan Tahun Pembelajaran 2016/2017. Asas: Jurnal Sastra, Vol. 6, no. 2, 2017.

Smith, F. 1981. "Myths of Writing" dalam Language Arts, 58, 7, hal. 792-798.

Somodana, Wyn, I.B Sutresna, dan Md Sri Indriani. 2015. Penerapan Model Pembelajaran Berbasis Masalah (Problem Based Learning) dalam Pembelajaran Menulis Teks Anekdot. e-Journal Jurusan Pendidikan Bahasa dan Sastra Indonesia Universitas Ganesha, Vol. 3 (1), 2015, 1-10. file:///C:/Users/ZET.COM/AppData/L ocal/Temp/30-4773-1-SM-1.pdf

Sugiyono. 2017. Metode Penelitian Kuantitatif, Kualitatif, $R \quad \& \quad D$. Bandung: CV. Alfabeta

Wulandari, Mei. 2020. Fostering Students' Love Of Writing At Elementary School. ISCE: Journal of Innovative Studies on Character and Education, Vol. 4 (2), 2020, 302-311. http://iscjournal.com/index.php/isce

Yuan, H., et al. 2008. Promoting Critical Thinking Skills Through ProblemBased Learning. Journal of social Science and Humanities. Vol. 2, No.2. 